\title{
Indicator Analysis as a Tool for Assessing the Functioning of a Modern Production Company
}

\author{
Robert Dmuchowski*, Stanisław Szmitka \\ Olsztyn College, Department of Economics, Poland, 10-288 Olsztyn, street: Jagielońska 59.
}

*Corresponding Author: Robert Dmuchowski, Olsztyn College, Department of Economics, Poland, 10 288 Olsztyn, street: Jagielońska 59.

\begin{abstract}
The primary goal of any business is to make a profit. Sometimes incurred costs exceed the obtained revenues and a business brings losses. In this case, a financial analysis is an irreplaceable tool for correcting decisions. Each business entity which wishes to develop and maintain an appropriate position in the industry and on the market must constantly monitor its property and financial situation. By means of financial analysis, a company examines its economic past and indicates areas of activity that are more or less profitable. Based on the achieved financial and economic results, a company develops the concept and management strategy as well as directions of future business activity.
\end{abstract}

The purpose of the article is to present the methods of examining the assessment of a market situation and financial analysis of the company "Dębica Joint Stock Company "in the years 2015-2017.

Keywords: indicator analysis, financial analysis, financial indicators, balance sheet, profit and loss account, financial result.

\section{INTRODUCTION}

Financial analysis is a process that evaluates previous results and allows to improve them or to change approach to the issues under consideration, and in particular it provides the opportunity to verify the effectiveness of operations expressed in financial condition. The goal of financial analysis comes down to assessing the rationality of the company's financial management in the past, diagnosing the current state and determining how to act in the future.

Business running involves a continuous decision making process. These decisions not only affect current operations, but also apply to the future. The goal of every company is to maximize profits, therefore the rationality and effectiveness of enterprise management are recognized as the main problem. The analysis is not only a source of information about the financial situation, it is also one of the main tools used to eliminate decision errors. Analysis of the results of calculations allows to verify whether the previous decisions were correct and what the consequences were. It also gives the opportunity to respond to future situations. When assessing a company's condition, it is very important to select tools, to compare and correctly interpret the obtained results.

\section{LITERATURE REVIEW}

\subsection{Characteristics of Ratio Analysis.}

Financial statements contain rich economic content. Its knowledge and use for efficient management of a company requires the transformation of the data and this can be done by means of indicator analysis. Indicator analysis is more detailed than preliminary analysis of financial statements, it is also the most widely used tool for structural, time and spatial analysis. Indicator analysis enables the assessment of past and present results of operations. It also helps make appropriate improvement to areas that are not properly managed for better results in the future. The overall analysis makes it possible to assess and predict the company's financial condition[1].

The financial indicator is a relation of at least two financial quantities with a strict interpretation (they explain what problem can be measured and what it means). There are four main sets of indicators, as shown in Figure 1. 


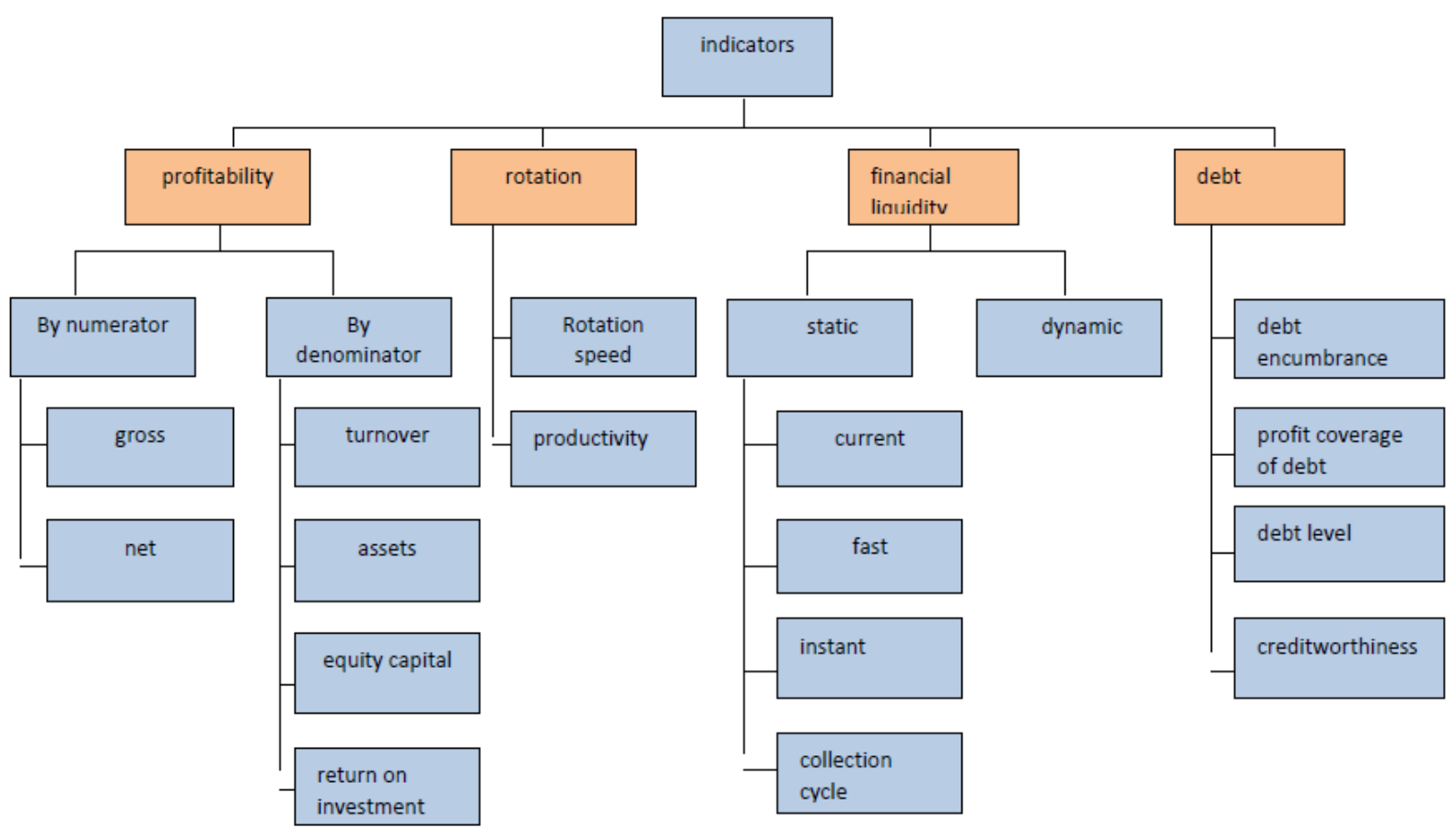

Figure1. Division of indicators in the analysis.

Source: Own study based on: https://pl.wikipedia.org/wiki/Wska\%C5\%BAniki_finansowe [2]

\subsection{Rotation Indicators.}

The effectiveness of the use of assets and capital in business can be assessed by performance indicators, also called turnover rates. These indicators include:

$$
\text { assets productivity ratio }=
$$

$$
\text { revenues from sales }
$$

average assets

This indicator informs about what revenues are generated by PLN 1 of involved in assets activities. A growing trend is a positive phenomenon because it indicates a better ability to use asset resources.

Another indicator is inventory turnover ratio in days (or times). The days turnover indicator determines how many days the stock is stored, while the indicator at times informs how many times a year the inventory is exchanged. The correct level of the indicator expressed in days depends on the type of business. Lower values are more favorable as they indicate lower costs of maintaining inventories and thus improving the efficiency of inventory management. Levels that are too low should be avoided as they may cause stopping sales or production stoppages. As for the indicator in times, the higher the values, the lower the degree of freezing funds in inventories. In order to learn the details, the turnover ratio should be determined for individual inventory items. The formula below shows the inventory turnover ratio:

$$
\text { inventory turnover in days }=
$$

\section{Inventory turnover ratio in times $=$}

average inventory $x 365$

$$
\begin{aligned}
& \text { revenues from sales } \\
& \text { revenues from sales }
\end{aligned}
$$

average inventory

An important factor in the analysis of turnover is the receivables turnover ratio in days or times. The ration expressed in days informs about the average number of days of receivables coming to a company. Too high a level indicates an excessively long lending to recipients. The decline in the indicator is assessed positively. The indicator calculated in times determines how many times a year the receivables are rotated. The higher its value, the greater the efficiency of debt collection from contractors and the greater the possibility of repayment of current liabilities. The indicator in days or in times is calculated from the formula: 
receivables turnover in days $=$

receivables turnover ratio in times $=$ average receivables $x 365$

revenues from sales
revenues from sales

average receivables

The opportunity to know how often short-term liabilities are settled gives a short-term liabilities rotation ratio in days or in times. A longer repayment period is more favorable, provided that this does not result in a loss of confidence on the part of suppliers:

average liabilities $x 365$

revenues from sales

Another indicator worth noticing is the cash turnover cycle on cash rotation in days :

inventory rotation cycle in days - inventory rotation in days +

receivables rotation in days - short-term liabilities rotation in days

This indicator informs about the number of days that pass from the moment of outflow of cash from an entity until its inflow. The shorter the cash rotation cycle, the lower the entity's demand for the use of external financing sources. A negative result indicates a stable position of the company on the market[3].

\subsection{Profitability Ratios}

Profitability is in other words cost effectiveness and generating a surplus of revenues over incurred costs[4]. In managing a company, it plays a key role, because one of the main goals of running business is making a profit. Profitability ratios are based on the relation of the amount of profit (from sales, from operating activities), for example, to revenues from sales of goods or total sales. The level of these indicators depends on the nature of the entity's operations. The increase in the size of indicators over time is interpreted positively.

The group of profitability indicators include:

Interpretation of this indicator provides information on how many groszy of profit on sales are generated by PLN 1 of achieved sales revenue.

$$
\text { net return on sales }=\quad \frac{\text { net profit }}{\text { total revenues }}
$$

This indicator answers the question how many groszy of net profit are generated by PLN 1 of total revenues. It should be remembered that total revenues is the sum of the amounts of revenues from basic activity, other operating revenues, financial revenues and extraordinary profits.

$$
\text { net return on assets }(R O A)=\quad \frac{\text { net profit }}{\text { total assets }}
$$

Thanks to the ROA indicator, it is possible to find out how much net profit an entity achieves from PLN 1 of assets involved in operations.

$\begin{aligned} \text { net return on current assets }= & \frac{\text { net profit }}{\text { assets }} \\ \text { net return on fixed assets }= & \text { fixe assets }\end{aligned}$


The two above indicators provide information on the amount of net profit per PLN 1 of current or fixed assets involved.

$$
\text { total capital net profitability ratio }=
$$

$$
\text { net profit }
$$

total capital

This indicator determines how much profit an entity generates from PLN 1 of the equity involved, including liabilities.

$$
\text { net return on equity }(R O E)=
$$

$$
\text { net profit }
$$$$
\text { equity capital }
$$

This ratio provides information about how much net profit is generated from PLN 1 of equity.

Financial liquidity ratios.

Financial liquidity means the entity's ability to pay its liabilities on time. Current assets are sold the fastest, but only part of them gives the possibility of immediate repayment of current liabilities. These are cash at hand and in bank accounts. Other ingredients, such as finished products, must be sold to make money from them. Liquidity ratios, according to the degree of liquidity, include:

- first degree ratio, which is the cash liquidity ratio;

- second degree ratio, which is quick liquidity ratio;

- the third degree ratio, which is the current liquidity ratio[5]

The cash (immediate) liquidity ratio is the relation of the most liquid current assets to current liabilities and explains the amount of payable liabilities an entity is able to cover from means of payment (cash on hand and on the bank account). This indicator should not be too high, because only cash resources involved in economic processes generate profits. It is assumed that the optimal value of the indicator is between 0.1 and 0.2.[6]

$$
\text { cash flow ratio }=\quad \frac{\text { cash }}{\text { current liabilities }}
$$

\section{RESEARCH}

Ration analysis of "Dębica Joint Stock Company (S.A.)" in 2015-2017.

The calculations were based on data from the balance sheet and profit and loss account.

\subsection{Rotation Analysis and Assessment}

The following indicators were used to analyze rotation:

- asset productivity ratio;

- inventory turnover ratio;

- receivables turnover ratio;

- rate of settling short-term liabilities;

- cash rotation cycle in days.

The calculated asset productivity ratio is presented in Figure 2, while the inventory, receivables and payables turnover ratios as well as the cash rotation cycle in days are illustrated in Figure 3.

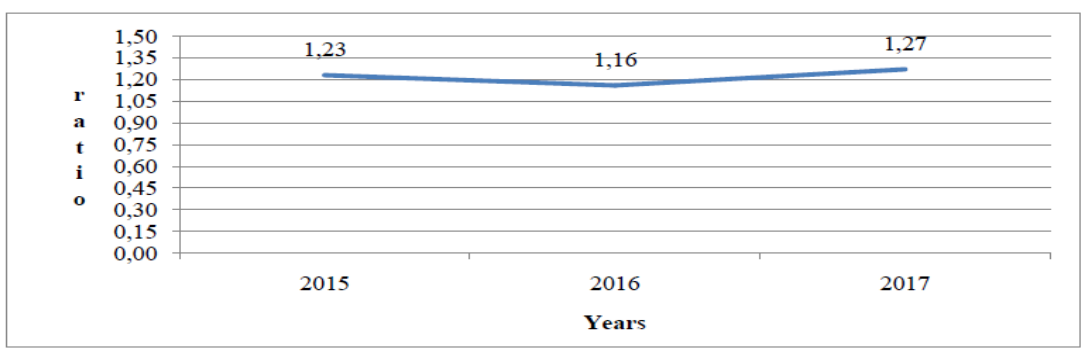

Figure2. Asset productivity indicator in the company "Dębica Joint Stock Company (S.A.)" 
Source: Own study based on data from the financial statements of "Dębica Joint Stock Company (S.A.)" [7]

In 2015, the company obtained PLN 1.23 of sales revenue from PLN 1 invested in assets. In the following year, they obtained PLN 0.07 less from the assets involved, but this level is still high. 2017 brought an increase to PLN 1.27 from 1 zloty engaged. this Such level of this indicator at evidence of efficient asset management.

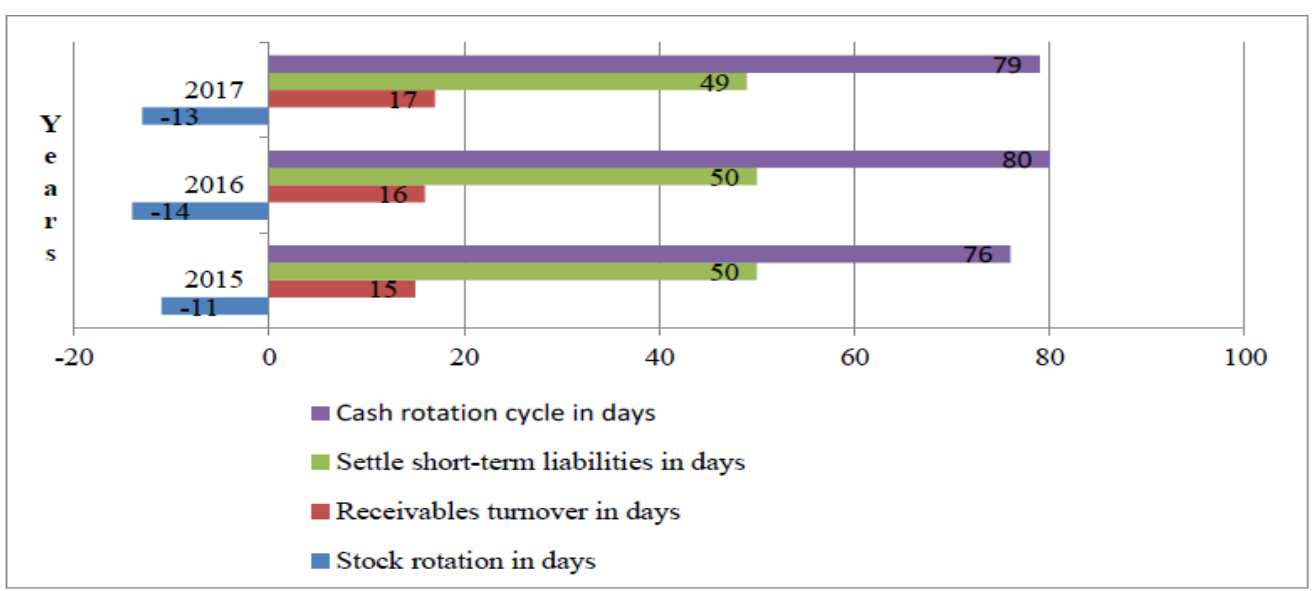

Figure3. Turnover ratios in the company "Dębica Joint Stock Company (S.A.)"

Source: Own study based on data from the financial statements of "Dębica Joint Stock Company [8]

The data presented above indicate that in 2015 the company renewed its reserves every 15 days. The values of this indicator increased to 16 days in 2016 and to 17 days in 2017. These values are appropriate for this type of business. Increase in the value of this indicator is not assessed positively in the literature, however, in the analyzed years it is a small increase which could be influenced by some factors, for example, the purchase of more materials at the end of the year before the increase in prices of raw materials in subsequent periods.

Receivables turnover in the analyzed years remained at a similar level, and in 2017 there was a decrease by 1 day. There were big differences between receiving receivables and paying off liabilities: 26 days in 2015 and 30 days in subsequent years. It is desirable for both of these indicators to be at a similar level, as this would indicate that the company repays its liabilities approximately at the same time as it receives the receivables. However, the fact of such debt collection is positive, which is confirmed by the negative cash rotation cycle indicator, characteristic of the strong position of the entity on the market.

\subsection{Profitability Analysis and Assessment}

Profitability or cost effectiveness is an important aspect in financial analysis because the company's financial position depends on the profits made. The following indicators were used to assess profitability in this subsection:

- return on sales ratio;

- net return on assets;

- net return on fixed assets;

- net return on current assets;

- return on equity ratio.

Good financial standing is reflected only by the positive values of these indicators.

Figure 4 shows the development of the return on sales ratio.

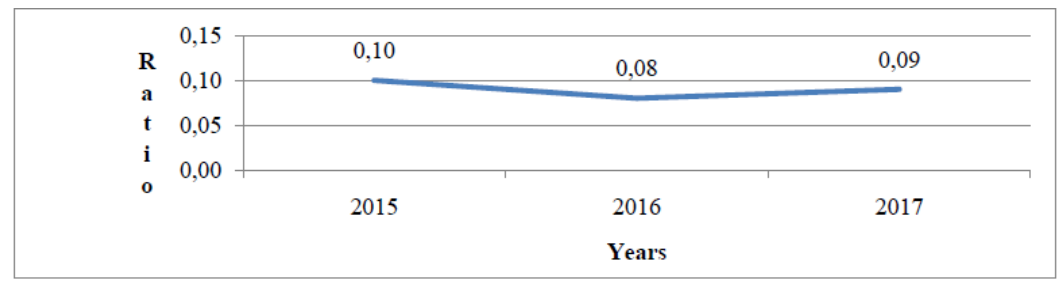

Figure4. Return on sales ratio in the company "Dębica Joint Stock Company" 
Source: Own study based on data from the financial statements of "Dębica Joint Stock Company"

\subsubsection{Financial Liquidity Analysis and Assessment}

The smooth functioning of every company also depends on financial liquidity as its negligence can even cause bankruptcy. To assess the financial liquidity of the company "Dębica Joint Stock Company" three main indicators were used:

- cash flow ratio;

- quick liquidity ratio;

- current liquidity ratio.

The cash flow ratio was at a varying level, from improper to normal, as shown in figure 5.

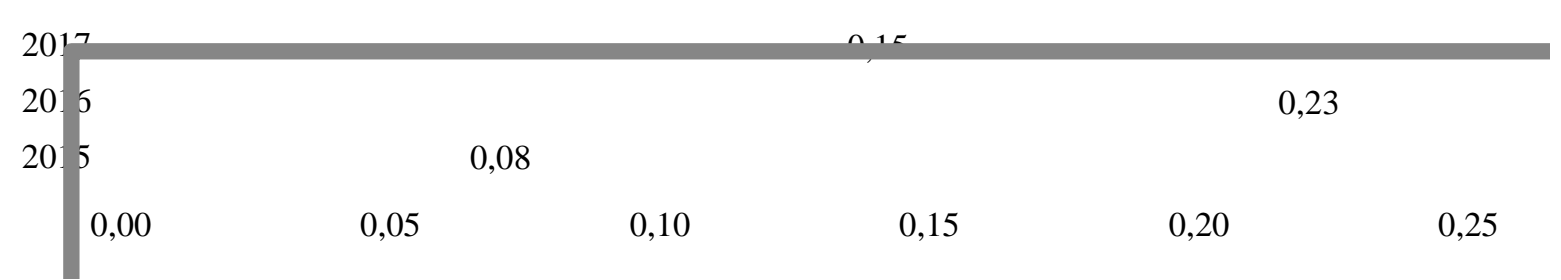

Figure5. Cash flow ratio of "Dębica Joint Stock Company"

Source: Own study based on data from the financial statements of "Dębica Joint Stock Company" [9]

In 2015, the level of cash flow ratio was alarmingly low, as its lower value should not be less than 0.1. In 2016, there was an improvement and the indicator slightly exceeded the upper limit. It can be seen that the company was taking steps to obtain the correct level of this indicator, which was 0.15 in 2017. The higher the cash liquidity ratio, the more it increases the instant repayment capacity of current liabilities, however, only money involved in business processes generates profits.

The last ratio, important in financial liquidity, is the current liquidity ratio. The evolution of this indicator in the years under review in the company "Dębica" is presented in Figure 6. It can be seen that the current liquidity remained at the correct level, which is the range between 1.5 and 2 and even increased. The company did not have any problems paying off its current liabilities at that time due to the liquidation of its current assets.

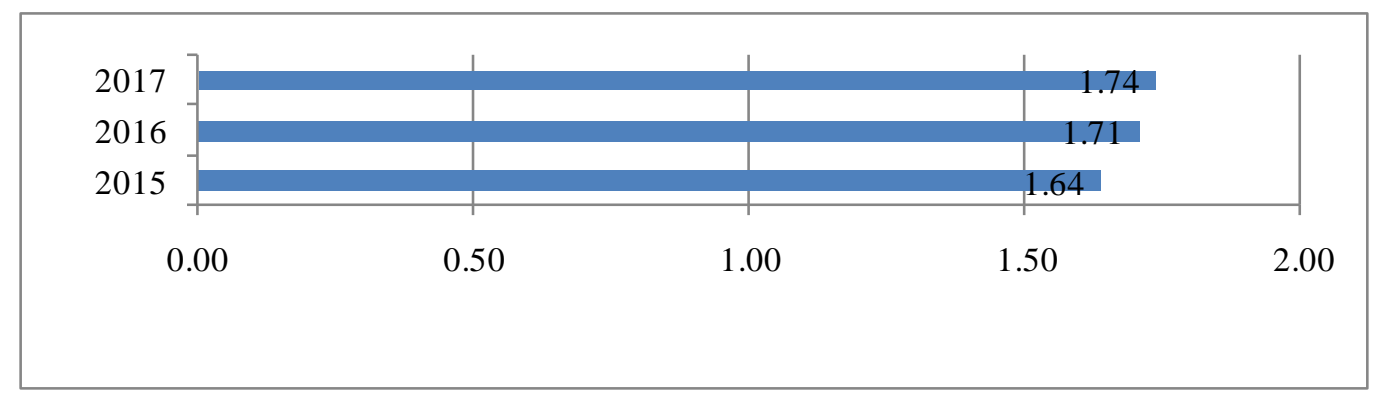

Figure6. Current liquidity ratio in the company "Dębica"

Source: Own study based on data from the financial statements of "Dębica" [10]

\subsection{Debt Analysis and Assessment}

Thanks to the indicators, it is also possible to assess the level of debt, which informs about the extent to which a company finances its activity with foreign capital.

The following indicators were used to analyze the debt:

- general debt;

- equity debt;

- equity participation in financing assets.

Figure 7 shows the overall debt ratio. In 2015 and 2016, the level of foreign capital in financing the company's assets was $26 \%$ and increased to $29 \%$ in the last of the surveyed years. The increasing 
value of this ratio and exceeding the level of $67 \%$ reflects the increasing risk for lenders, however in the case of the analyzed data of the company "Dębica Joint Stock Company" this condition is not a threat.

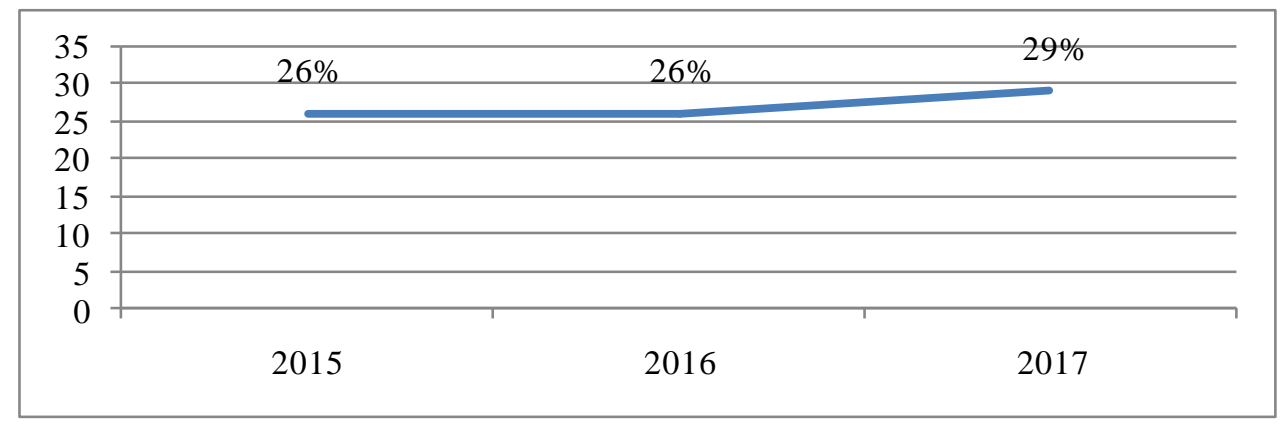

Figure7. General debt ratio in the company "Dębica Joint Stock Company."

Source: Own study based on data from the financial statements of "Dębica Joint Stock Company"

The level of equity ratio is also assessed positively. The lower its value, the smaller the company's dependence on foreign capital.

The share of equity in financing assets, illustrated in Figure 8, was not at an ideal level of 100\%, although it fluctuated quite high. In 2015, its value was $70 \%$, the following year it increased by $1 \%$, while in 2017 it decreased to $67 \%$. Its decrease is assessed negatively.

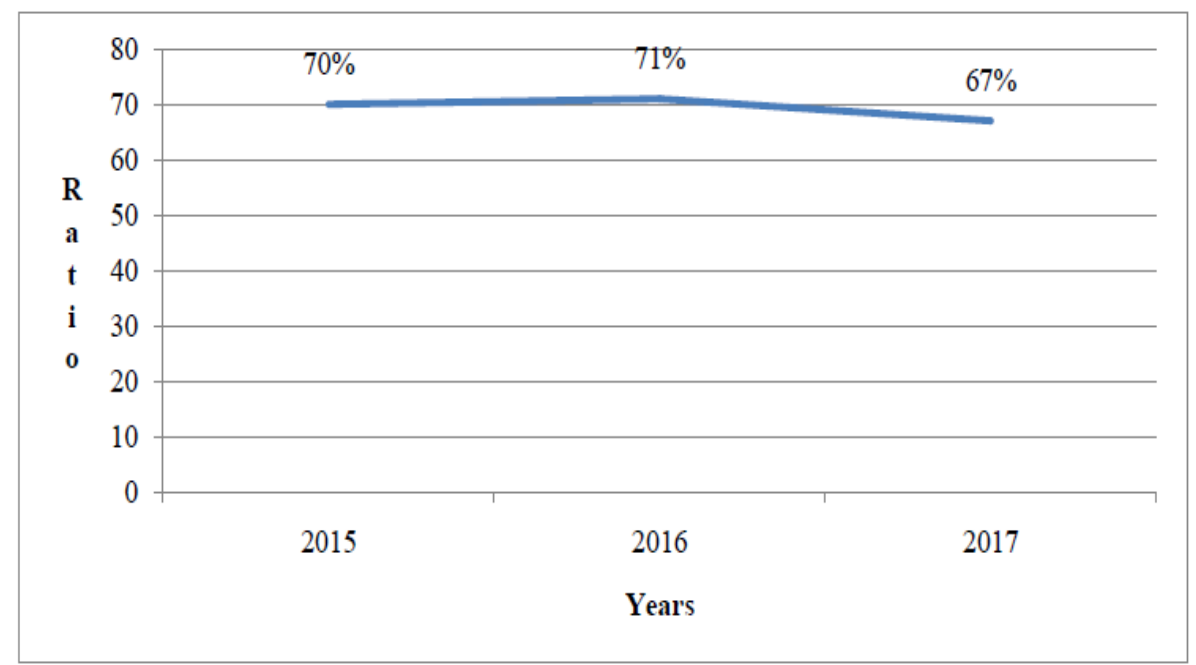

Figure8. Indicator of the share of equity in financing assets in the tire company "Dębica"

Source: Own study based on data from the financial statements of "Dębica "

\section{CONCLUSION}

The choice of indicators in this article was guided by the possibility of obtaining confirmation of the thesis that financial analysis helps to detect areas less well managed in a company.

Preliminary analysis of the financial statements revealed their structure and dynamics showed correct trends in the years2015-2017, including an increase in total assets. The structure of assets decreased from over $57 \%$ to $49.50 \%$, while the share of current assets increased. The greater share of current assets over non-current assets in the balance sheet total means greater flexibility when it is necessary to change a production type. Equity constituted a greater part of sources of financing assets in the analyzed years in the company "Dębica" and its share ranged from $67.5 \%$ to $70.6 \%$. In each of the researched years the company experienced a profit that decreased in 2016, and in 2017 almost doubled its value from the year. In 2016, sales revenues fell more than costs decreased, which contributed to a decrease in gross sales profit by $22.08 \%$. In 2017, there was an increase in sales revenues by $14.67 \%$, and slower rising costs enabled an increase in gross profit on sales by $29.50 \%$. In 2016, the decrease in sales profit was influenced by an increase in sales costs by $127 \%$, which in the following year decreased along with general and administrative expenses and contributed to an 
increase in sales profit by $105.84 \%$ compared to 2016 . Other operating revenues increased in the studied years, while other operating costs decreased. Such a level of other operating revenues and costs caused a decrease in operating profit. In 2016, financial income increased significantly more slowly than financial costs, which had a negative impact on business profit. The final net result decreased in 2016 and then increased in 2017. The "cash-flow" analysis showed that the company had one of the best scenarios, as the proceeds from its main activity allowed to finance investments in assets and to repay loans to banks.

The company coped well with inventory, receivables and payables management in the studied years. The cash rotation cycle showed a negative balance, i.e. confirmed good financial condition. Profitability and liquidity ratios showed a strong market position and no solvency problems. All assets are profitable, which means that they are managed efficiently. The quick and current liquidity ratio fluctuated at an almost standard level. Debt ratios also do not indicate that the condition of the tire company "Dębica " is bad. The company mostly finances its assets with equity, and is not dependent on foreign capital to a significant extent.

The calculations, their analysis and interpretation made it possible to state that the tire company "Dębica Joint Stock Company" had a proper financial condition and a stable market position in the audited period.

\section{REFERENCES}

[1] Kurtys E.,Economic analysis of the enterprise, Wrocław 1996, publishing House of the Oskar Lange.

[2] https://pl.wikipedia.org/wiki/Wska\%C5\%BAniki_finansowe [access: 19.03.2019]

[3] Padurek B., Accounting Office, Wrocław 2014, publishing Bożena Padurek

[4] Dunaj B., Popular dictionary of the Polish language, Warszawa 2007, WILGA.

[5] Sierpińska M. and Jachna T., Assessment of the enterprise according to world standards, Warszawa 2011, PW

[6] Bednarski L., Financial analysis in the enterprise, Warszawa 2007, PWE

[7] https://www.krs-online.com.pl/firma-oponiarska-debica-s-a-krs-43000.htm [access: 03.03.2019]

[8] https://notowania.pb.pl/instrument/PLDEBCA00016/debica/informacje-spolka[access: 03.03.2019r.]

[9] https://www.debica.com.pl/o_firmie [access: 02.03.2019r.]

[10] https://www.debica.com.pl/o_firmie/historia [access: 02.03.2019r.]

\section{AUTHOR'S BIOGRAPHY}

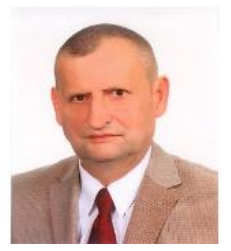

Stanisław SZMITKA, PhD in Economics. Assistant professor at the University of Olsztyn in Olsztyn. Program director and head of the Department of Economics. Theorist and economic practitioner. President of the Management Board of the Capital Company, member of Supervisory Boards. Member of the Scientific Council of the Olsztyn Science Park. He is interested in the problems of the functioning of a modern enterprise in the realities of the market economy, in particular innovation and competitiveness. Author of numerous works in this field (Greece, Bulgaria, Ukraine, Russia, Poland). Supervisor of bachelor\&\#39;s and master\&\#39;s theses.

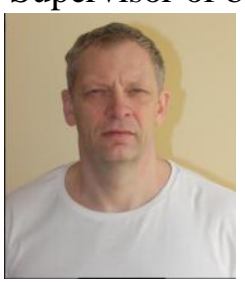

Robert DMUCHOWSKI, graduated of the University of Economics in Poznań, doctor of economic sciences in the field of Transport and Logistics. Assistant professor at the University of Olsztyn in Olsztyn. In his scientific work, he deals with issues in the field of logistiscs, entrepreneurship and innovation. Author of numerous monographs and articles published in Poland and abroad, in which issues related to the market economy and regional development are discussed.

Citation: Robert Dmuchowski, Stanisław Szmitka. " Indicator Analysis as a Tool for Assessing the Functioning of a Modern Production Company "International Journal of Managerial Studies and Research (IJMSR), vol 8, no. 8, 2020, pp. 74-81. doi: https://doi.org/10.20431/2349-0349.0808008.

Copyright: (C) 2020 Authors. This is an open-access article distributed under the terms of the Creative Commons Attribution License, which permits unrestricted use, distribution, and reproduction in any medium, provided the original author and source are credited. 